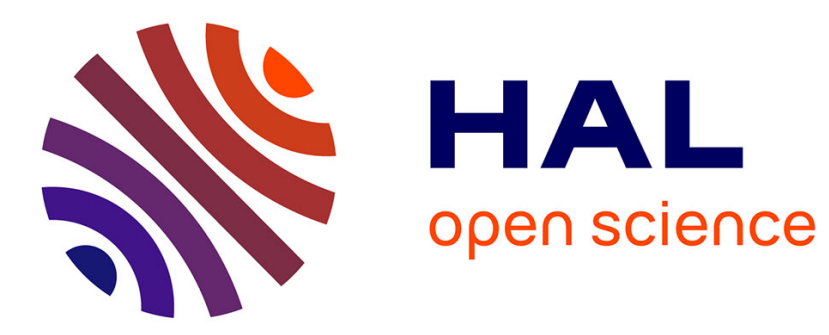

\title{
Filling the equatorial garland of uranyl ion: its content and limitations
}

\author{
Youssef Atoini, Jack Harrowfield, Yang Kim, Pierre Thuéry
}

\section{To cite this version:}

Youssef Atoini, Jack Harrowfield, Yang Kim, Pierre Thuéry. Filling the equatorial garland of uranyl ion: its content and limitations. Journal of Inclusion Phenomena and Macrocyclic Chemistry, In press, 10.1007/s10847-021-01048-8 . cea-03148183

\section{HAL Id: cea-03148183 https://hal-cea.archives-ouvertes.fr/cea-03148183}

Submitted on 22 Feb 2021

HAL is a multi-disciplinary open access archive for the deposit and dissemination of scientific research documents, whether they are published or not. The documents may come from teaching and research institutions in France or abroad, or from public or private research centers.
L'archive ouverte pluridisciplinaire HAL, est destinée au dépôt et à la diffusion de documents scientifiques de niveau recherche, publiés ou non, émanant des établissements d'enseignement et de recherche français ou étrangers, des laboratoires publics ou privés. 
Filling the equatorial garland of uranyl ion: its content and limitations

Youssef Atoini ${ }^{1,2} \cdot$ Jack Harrowfield $^{1} \cdot$ Yang Kim $^{3} \cdot$ Pierre Thuéry $^{4}$

${ }^{1}$ ISIS, Université de Strasbourg, 8 allée Gaspard Monge, 67083 Strasbourg, France

E-mail: harrowfield@unistra.fr

2 Present address: Technical University of Munich - Campus Straubing, Schulgasse 22, 94315 Straubing, Germany

${ }^{3}$ Department of Chemistry, Graduate School of Science and Technology, Kumamoto University, 2-39-1 Kurokami, Chuo-ku, Kumamoto 860-8555, Japan

${ }^{4}$ Université Paris-Saclay, CEA, CNRS, NIMBE, 91191 Gif-sur-Yvette, France

E-mail: pierre.thuery@cea.fr

Dedicated to the memory of Jacques Vicens, a man for whom chemistry was truly an art.

\begin{abstract}
Crystal structure determinations on the uranyl ion complexes $\left.\left[\mathrm{H}_{2} \mathrm{~N}\left(\mathrm{CH}_{3}\right)_{2}\right]_{2}\left[\mathrm{UO}_{2} \text { (bpdc) }\right)_{2}\right], \quad(\mathbf{1}), \quad($ bpdc $=$ 2,2'-bipyridine-3,3'-dicarboxylate), $[\mathrm{pyH}]_{2}\left[\mathrm{UO}_{2}\right.$ (btfac) $\left.\left(\mathrm{NO}_{3}\right)_{2}\right]\left(\mathrm{NO}_{3}\right), \quad(2), \quad($ btfac $=$ 1-phenyl-4,4,4-trifluorobutane-1,3dionate), $\left[\mathrm{H}_{2} \mathrm{dabco}\right]\left[\mathrm{UO}_{2}(\mathrm{nta})\right]_{2} \cdot 3 \mathrm{H}_{2} \mathrm{O},(3),($ dabco $=1$,4-diazabicyclo[2.2.2]octane; nta = nitrilotriacetate) and $\left[\mathrm{Ni}(\right.$ cyclam $) \mathrm{UO}_{2}($ edta $\left.)\right] \cdot 2 \mathrm{H}_{2} \mathrm{O}, \quad(4), \quad($ cyclam $=1,4,8,11-$ tetrazacyclotetradecane; edta = ethylenediaminetetraacetate) have provided further examples of U(VI) in tetragonal-, pentagonal and hexagonal-bipyramidal coordination environments. Consideration of each structure within the context of those of known relatives has been used to assess the influence of factors in addition to repulsions within the primary coordination sphere on the equatorial coordination number of U(VI).
\end{abstract}

Keywords Uranyl ion complexes · Structure determination · Hydrogen bonding

\title{
Declarations
}

Funding No funding.

Conflicts of interest/Competing interests The authors have no conflicts of interest to declare that are relevant to the content of this article.

Availability of data and material All data generated or analysed during this study are included in this published article.

Code availability Not applicable. 


\section{Introduction}

The high oxophilicity [1] of uranium(VI), reflected basically in the nature of its wellknown form as that of uranyl ion, $\mathrm{UO}_{2}{ }^{2+}[2]$, as well as in the difficulty of obtaining the simple aza-analogue of this cation [3], remains operative in the secondary coordination interactions which give rise to the array of donor atoms lying close to one plane perpendicular to the linear O-U-O unit and found almost universally in compounds regarded formally as containing the uranyl cation $[2,4]$. X-ray crystallographic studies, especially numerous in the case of carboxylate species $[5,6,7]$, have shown that in the solid state this "equatorial garland" may contain different numbers of donor atoms varying between three (e.g. [HNEt $]$ [ $\mathrm{UO}_{2}$ (hexahomotrioxacalix[3]arene - 3H)] and related species $[8,9]$ and $\left.\left[\mathrm{Na}(\text { thf })_{2}\right]\left[\mathrm{UO}_{2}\left\{\mathrm{~N}\left(\mathrm{SiMe}_{3}\right)_{2}\right\}_{3}\right][10]\right)$ and six (e.g. $\mathrm{Na}\left[\mathrm{UO}_{2}(\mathrm{OAc})_{3}\right]$ [11]), though with five or six being most frequent. The U(VI) aqua ion has been shown to have a pentagonal-bipyramidal form as $\left[\mathrm{UO}_{2}\left(\mathrm{OH}_{2}\right)_{5}\right]^{2+}$ in both the solid state and solution through XRD [12-14] and EXAFS measurements allied to computational studies [14-16] but what is very obvious in the crystal structure determinations is that this cation is involved in multiple H-bonding interactions with its environment, raising the question as to what influence such interactions may have on the equatorial coordination number. While H-bonding is certainly well-recognised as a factor influencing solid state structures of uranyl ion carboxylate complexes in particular [5,6,7], as well as in less abundant species (e.g. phosphonates [17]), it has not usually been assessed in terms of any influence upon the equatorial coordination sphere. To some extent, the use of terminology related to the idealised geometry of uranyl ion environments in describing them as, for example, pentagonal- or hexagonal-bipyramidal, disguises the fact that the equatorial donor atoms are rarely truly coplanar, and it should be noted that there are instances where deviations from this situation are quite dramatic $[18,19]$. Thus, in the present work we describe structural studies of a heterogeneous group of uranyl ion complexes with the specific objective of perceiving factors, not only H-bonding, which may influence equatorial coordination numbers and geometry. 


\section{Experimental}

Synthesis

Caution! Uranium is a radioactive and chemically toxic element, and uranium-containing samples must be handled with suitable care and protection. Small quantities of reagents and solvents were employed to minimise any potential hazards arising both from the presence of uranium and the use of pressurised vessels for the syntheses.

$\left[\mathrm{UO}_{2}\left(\mathrm{NO}_{3}\right)_{2}\left(\mathrm{H}_{2} \mathrm{O}\right)_{2}\right] \cdot 4 \mathrm{H}_{2} \mathrm{O}$ (RP Normapur, 99\%) was purchased from Prolabo. 2,2'bipyridine-3,3'-dicarboxylic acid ( $\mathrm{H}_{2}$ bpdc) and 1-phenyl-4,4,4-trifluorobutane-1,3-dione (benzoyltrifluoroacetone $=\mathrm{Hbtfac}$ ) were obtained from Aldrich, nitrilotriacetic acid from Fluka and ethylenediaminetetraacetic acid disodium salt dihydrate from Sigma. [Ni(cyclam) $\left.\left(\mathrm{NO}_{3}\right)_{2}\right]$ was synthesized as previously described [20].

[H $\left.\mathrm{H}_{2} \mathrm{~N}\left(\mathrm{CH}_{3}\right)_{2}\right]_{2}\left[\mathrm{UO}_{2}\right.$ (bpdc) 2$]$ (1). 2,2'-bipyridine-3,3'-dicarboxylic acid (24 $\mathrm{mg}, 0.10 \mathrm{mmol}$ ), $\left[\mathrm{UO}_{2}\left(\mathrm{NO}_{3}\right)_{2}\left(\mathrm{H}_{2} \mathrm{O}\right)_{2}\right] \cdot 4 \mathrm{H}_{2} \mathrm{O}$ (35 mg, $\left.0.07 \mathrm{mmol}\right)$, and $\mathrm{PPh} 3 \mathrm{MeBr}(36 \mathrm{mg}, 0.10 \mathrm{mmol}$ ) were dissolved in a mixture of water $(0.8 \mathrm{~mL})$ and DMF $(0.2 \mathrm{~mL})$. The solution was placed in a $10 \mathrm{~mL}$ tightly closed glass vessel and heated at $140{ }^{\circ} \mathrm{C}$ in a sand bath, under autogenous pressure, giving a few yellow crystals of complex 1 within one month.

$[\mathrm{pyH}]_{2}\left[\mathrm{UO}_{2}\right.$ (btfac) $\left.\left(\mathrm{NO}_{3}\right)_{2}\right]\left(\mathrm{NO}_{3}\right)$ (2). 1-phenyl-4,4,4-trifluorobutane-1,3-dione (22 mg, $0.10 \mathrm{mmol}$ ) was added to a solution of $\left[\mathrm{UO}_{2}\left(\mathrm{NO}_{3}\right)_{2}\left(\mathrm{H}_{2} \mathrm{O}\right)_{2}\right] \cdot 4 \mathrm{H}_{2} \mathrm{O}(25 \mathrm{mg}, 0.05 \mathrm{mmol})$ in pyridine $(2 \mathrm{~mL})$ and the orange solution formed was kept at $90{ }^{\circ} \mathrm{C}$ for $24 \mathrm{~h}$ before being allowed to slowly evaporate at room temperature to provide pale yellow crystals.

$\left[\mathrm{H}_{2}\right.$ dabco $]\left[\mathrm{UO}_{2}(\mathrm{nta})\right]_{2} \cdot 3 \mathrm{H}_{2} \mathrm{O}$ (3). Nitrilotriacetic acid $(19 \mathrm{mg}, 0.10 \mathrm{mmol})$, $\left[\mathrm{UO}_{2}\left(\mathrm{NO}_{3}\right)_{2}\left(\mathrm{H}_{2} \mathrm{O}\right)_{2}\right] \cdot 4 \mathrm{H}_{2} \mathrm{O}(35 \mathrm{mg}, 0.07 \mathrm{mmol})$, and dabco $(22 \mathrm{mg}, 0.20 \mathrm{mmol})$ were dissolved in a mixture of water $(0.8 \mathrm{~mL})$ and DMF $(0.2 \mathrm{~mL})$. The solution was placed in a $10 \mathrm{~mL}$ tightly closed glass vessel and heated at $140{ }^{\circ} \mathrm{C}$ in a sand bath, under autogenous pressure, giving a few yellow crystals of complex $\mathbf{3}$ overnight.

$\left[\mathrm{Ni}(\right.$ cyclam $) \mathrm{UO}_{2}($ edta $\left.)\right] \cdot 2 \mathrm{H}_{2} \mathrm{O}$ (4). Ethylenediaminetetraacetic acid disodium salt dihydrate (37 mg, $0.10 \mathrm{mmol}),\left[\mathrm{UO}_{2}\left(\mathrm{NO}_{3}\right)_{2}\left(\mathrm{H}_{2} \mathrm{O}\right)_{2}\right] \cdot 4 \mathrm{H}_{2} \mathrm{O}(35 \mathrm{mg}, 0.07 \mathrm{mmol})$, and [Ni(cyclam) $\left.\left(\mathrm{NO}_{3}\right)_{2}\right](20 \mathrm{mg}, 0.05 \mathrm{mmol})$ were dissolved in a mixture of water $(1.3 \mathrm{~mL})$ 
and DMF (0.4 mL). The solution was placed in a $10 \mathrm{~mL}$ tightly closed glass vessel and heated at $140{ }^{\circ} \mathrm{C}$ in a sand bath, under autogenous pressure, giving a few yellow crystals of complex 4 within ten days.

\section{Crystallography}

The data were collected at 100(2) K (180(2) K for 1) either on a Nonius Kappa-CCD area detector diffractometer [21] using graphite-monochromated Mo $\operatorname{K\alpha }$ radiation $(\lambda=$ $0.71073 \AA$ ) (complexes 1 and 4), or on a Bruker D8 Quest diffractometer equipped with an Incoatec Microfocus Source (I $\mu \mathrm{S} 3.0 \mathrm{Mo}$ ) and a PHOTON III area detector, and operated through the APEX3 software [22] (complexes 2 and 3). The crystals were mounted into glass capillaries or on Mitegen micromounts with a protective coating of Paratone-N oil (Hampton Research). The data were processed with HKL2000 [23] or SAINT [24], and absorption effects were corrected for empirically with SCALEPACK [23] or SADABS [25]. All structures were solved by intrinsic phasing with SHELXT [26], expanded by subsequent difference Fourier synthesis and refined by full-matrix leastsquares on $F^{2}$ with SHELXL [27], using the ShelXle interface [28]. All non-hydrogen atoms were refined with anisotropic displacement parameters. The $\mathrm{CF}_{3}$ group in $\mathbf{2}$ is rotationally disordered over two sites which were refined with occupancy parameters constrained to sum to unity and with restraints on bond lengths and displacement parameters. The $\mathrm{H}_{2}$ dabco cation in $\mathbf{3}$ is disordered over two positions sharing one nitrogen atom located on a twofold rotation axis, which were refined with restraints on bond lengths and displacement parameters. When present, the hydrogen atoms bound to oxygen and nitrogen atoms were retrieved from difference electron density maps, except in 3, in which they were introduced at calculated positions, and they were either treated as riding atoms (1, 3 and 4) or refined (2). The carbon-bound hydrogen atoms were introduced at calculated positions and were treated as riding atoms with an isotropic displacement parameter equal to 1.2 times that of the parent atom $\left(1.5\right.$ for $\mathrm{CH}_{3}$, with optimized geometry). Crystal data and structure refinement parameters are given in Table 1. The molecular plots were drawn with ORTEP-3 [29] and the polyhedral representations with VESTA [30]. The topological analyses were made with ToposPro [31]. 
Table 1 Crystal data and structure refinement details

\begin{tabular}{|c|c|c|c|c|}
\hline Complex & 1 & 2 & 3 & 4 \\
\hline chemical formula & $\mathrm{C}_{28} \mathrm{H}_{28} \mathrm{~N}_{6} \mathrm{O}_{10} \mathrm{U}$ & $\mathrm{C}_{20} \mathrm{H}_{18} \mathrm{~F}_{3} \mathrm{~N}_{5} \mathrm{O}_{13} \mathrm{U}$ & $\mathrm{C}_{18} \mathrm{H}_{32} \mathrm{~N}_{4} \mathrm{O}_{19} \mathrm{U}_{2}$ & $\mathrm{C}_{20} \mathrm{H}_{40} \mathrm{~N}_{6} \mathrm{NiO}_{12} \mathrm{U}$ \\
\hline$M\left(\mathrm{~g} \mathrm{~mol}^{-1}\right)$ & 846.59 & 831.42 & 1075.53 & 853.32 \\
\hline crystal system & triclinic & triclinic & orthorhombic & triclinic \\
\hline space group & $P \overline{1}$ & $P \overline{\mathrm{l}}$ & Pbcn & $P \overline{1}$ \\
\hline$a(\AA)$ & $8.9493(5)$ & $9.8827(10)$ & $19.5372(6)$ & $8.6919(7)$ \\
\hline$b(\AA)$ & $9.3209(4)$ & $11.6479(12)$ & $13.2256(4)$ & $8.7086(7)$ \\
\hline$c(\AA)$ & $9.5887(5)$ & $11.9803(12)$ & $11.1800(3)$ & $11.5053(6)$ \\
\hline$\alpha\left(^{\circ}\right)$ & $82.526(3)$ & $73.140(5)$ & 90 & $80.459(5)$ \\
\hline$\beta\left(^{\circ}\right)$ & $75.729(3)$ & $85.557(5)$ & 90 & $86.449(5)$ \\
\hline$\gamma\left(\left(^{\circ}\right)\right.$ & $75.748(3)$ & $83.148(5)$ & 90 & $61.767(4)$ \\
\hline$V\left(\AA^{3}\right)$ & $749.25(7)$ & $1309.0(2)$ & 2888.81(15) & $756.53(10)$ \\
\hline$Z$ & 1 & 2 & 4 & 1 \\
\hline reflections collected & 35204 & 116001 & 130802 & 32125 \\
\hline independent reflections & 2844 & 6762 & 2743 & 2869 \\
\hline observed reflections $[I>2 \sigma(I)]$ & 2805 & 6288 & 2421 & 2524 \\
\hline$R$ int & 0.063 & 0.069 & 0.068 & 0.051 \\
\hline parameters refined & 207 & 415 & 240 & 184 \\
\hline$R_{1}$ & 0.026 & 0.033 & 0.030 & 0.034 \\
\hline$w R_{2}$ & 0.062 & 0.102 & 0.063 & 0.066 \\
\hline$S$ & 1.055 & 1.105 & 1.066 & 0.993 \\
\hline$\Delta \rho_{\min }\left(\mathrm{e} \AA^{-3}\right)$ & -1.68 & -1.50 & -3.91 & -1.05 \\
\hline$\Delta \rho_{\max }\left(\mathrm{e} \AA^{-3}\right)$ & 1.23 & 3.62 & 2.89 & 0.92 \\
\hline CCDC reference number & 2046316 & 2046317 & 2046318 & 2046319 \\
\hline
\end{tabular}

\section{Results and discussion}

The syntheses of all the presently described materials are all trivial and do not warrant discussion other than to note that they exemplify extremes of common currently adopted procedures in that complex 2 was obtained by simple evaporation of an appropriate mixture of reagents (intended to provide the bis(diketonate) complex) under ambient conditions, whereas complexes 1, 3 and 4 were obtained by solvohydrothermal methods and were crystallised under conditions of elevated pressure and temperature. The composition of the isolated materials is no doubt a reflection of the conditions of synthesis but our interest was focussed upon an analysis of their structures only.

The ligand 2,2'-bipyridine-3,3'-dicarboxylate (bpdc ${ }^{2-}$ ) is found in complex $\mathbf{1}$ as a simple 0,0 -chelate involving unidentate- 0 coordination of both carboxylate groups in a centrosymmetric, mononuclear, bis(ligand), anionic species (Fig. 1). The U-O(oxo) bond 


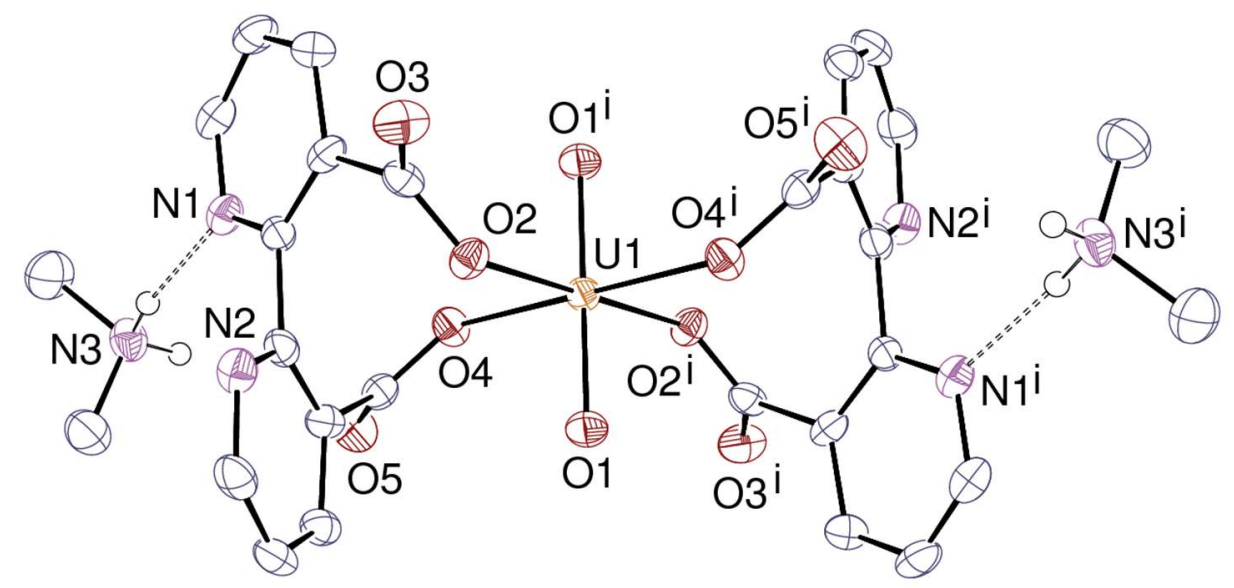

Fig. 1 View of $\left[\mathrm{H}_{2} \mathrm{~N}\left(\mathrm{CH}_{3}\right)_{2}\right]_{2}\left[\mathrm{UO}_{2}(\mathrm{bpdc})_{2}\right]$ (1). Displacement ellipsoids are drawn at the $50 \%$ probability level. Carbon-bound hydrogen atoms are omitted and hydrogen bonds are shown as dashed lines. Symmetry code: $\mathrm{i}=1-x, 1-y, 1-z$.

length of 1.780 (3) $\AA$ and the U-O (carboxylato) bond lengths of 2.263(3) and 2.338(2) $\AA$ do not depart from their usual values. In particular, the mean U-O(carboxylato) bond length for the structures of six-coordinated $U(V I)$ cations involving four equatorial carboxylate groups reported in the Cambridge Structural Database (CSD, Version 5.41) [32], is 2.30(2) $\AA$. The mode of coordination is unusual for the ligand, which is known to adopt $\mathrm{N}, \mathrm{N}$-chelation [33] or $\mathrm{N}, \mathrm{N}$-chelation plus O-coordination of one carboxylate [34] with $\mathrm{Cu}(\mathrm{II})$, bridging by coordination of one oxygen of each carboxylate with Mn(II) [35], association by further bridging-coordination of one oxygen of each carboxylate to two cations with $\mathrm{Na}(\mathrm{I})$ and $\mathrm{K}(\mathrm{I})$ [36], and bridging by an even more complicated mode

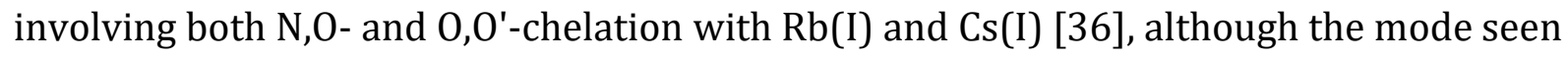
in complex 1 has recently been identified, along with others, in heterometallic uranyl ion complexes involving 2,2';2",6'-terpyridine as a co-ligand [37]. It could also be considered as an unusual coordination mode on the basis of the expected preference of a large metal cation for chelation by a small- rather than a large-bite ligand [38], i.e. by the bipyridine rather than the dicarboxylate unit, and by the fact that repulsive interactions around the biaryl link place the 0-donors rather far apart, although in fact the separation of the coordinated 0 atoms of bound bpdc- (3.334(8) $\AA$ ) is only slightly shorter than the minimum $0 \cdots 0$ separation in the parent acid $\mathrm{H}_{2}$ bpdc (3.457(9) $\AA$ ) [33] and $\mathrm{O}$ - rather than $\mathrm{N}$-coordination is of course consistent with the oxophilicity of uranyl ion. 
Thus, perhaps the most unusual feature of the structure of $\mathbf{1}$ is the square bipyramidal (octahedral) coordination of the mononuclear U(VI) centre, this being so for two reasons. One is simply that such coordination is rare in uranyl ion complexes generally other than with very simple ligands such as hydroxide $[5,6,15]$ and another is that for carboxylato complexes in particular it is best known for uranyl centres forming part of neutral, infinite polymer chains where the equatorial coordination is due to four $\mu_{2}-\kappa^{1} O, \kappa^{1} O^{\prime}$ bridging carboxylate units [6,39-43], although, as noted above, there are precedents [37] for the present observation of a mononuclear species. As well, U(VI) in both six- (octahedral) and seven- (pentagonal bipyramidal) coordination is found in the structures of two heterometallic uranyl ion coordination polymer complexes of 2,2'bipyridine-3,3';6,6'-tetracarboxylate (bptc ${ }^{4-}$ ) [43] where, possibly as a result of crowding around the six-coordinate centre, distortions from a regular octahedral geometry are considerably greater than in any other cases. For example, in the structure of $\left[\mathrm{Cd}\left(\mathrm{UO}_{2}\right)_{3}(\mathrm{bptc})_{2}\left(\mathrm{H}_{2} \mathrm{O}\right)_{2}\right]$, the two U2-O(carboxylate) bond lengths are 2.262(4) and 2.343(4) A, with (carboxylate)O-U-O(carboxylate) bond angles of 80.0 and $100.0^{\circ}$, while in [ $\mathrm{UO}_{2}$ (benzoate) 2 [39], the corresponding values are 2.38(1) $\AA$ (4 equivalent bonds), and 90.8 and $89.2^{\circ}$.

A significant comparison results from recognition that the ligand 2,2'-bipyridine3,3'-dicarboxylate is a diaza-analogue of diphenate (1,1'-biphenyl-2,2'-dicarboxylate = $\operatorname{dip}^{2-}$ ) and while the latter is known to form a variety of uranyl ion complexes with different coordination modes [44], it does form one anionic complex very similar to that in 1. The complex $\left.\left[\mathrm{Ni}\left(R, S-\mathrm{Me}_{6} \mathrm{cyclam}\right)\left(\mathrm{H}_{2} \mathrm{O}\right)_{2}\right]\left[\mathrm{UO}_{2} \text { (dip) }\right)_{2}\right]$ contains centrosymmetric $\left[\mathrm{UO}_{2}(\mathrm{dip})_{2}\right]^{2-}$ anions (chelating $0 \cdots 0$ 3.192(6) Å) linked into infinite chains through Hbonding to the coordinated water molecules of the countercation (Fig. 2a). More pertinent to the 


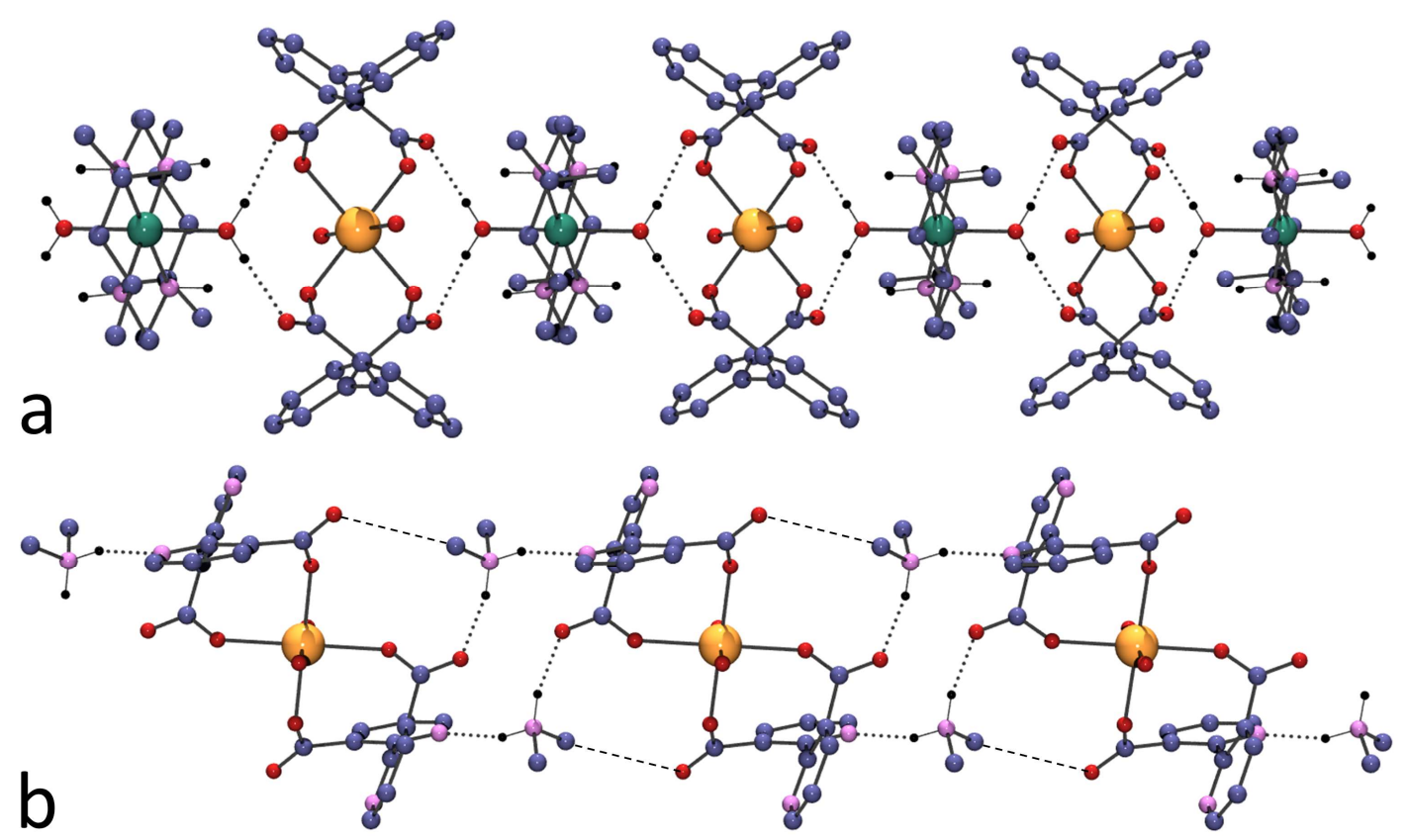

Fig. 2 Hydrogen-bonded chains in $\left[\mathrm{Ni}\left(R, S-\mathrm{Me}_{6} \mathrm{cyclam}\right)\left(\mathrm{H}_{2} \mathrm{O}\right)_{2}\right]\left[\mathrm{UO}_{2}(\mathrm{dip})_{2}\right]$ (a) and in $\mathbf{1}$ (b). Carbon-bound hydrogen atoms are omitted; $\mathrm{OH} \cdots \mathrm{O}$ and $\mathrm{NH} \cdots \mathrm{O} / \mathrm{N}$ hydrogen bonds are shown as dotted lines and $\mathrm{CH} \cdots \mathrm{O}$ bonds as dashed lines.

present work is the observation of exactly this mode of bridging by water in the isomorphous complexes [M(terpy) 2$]\left[\mathrm{UO}_{2}(\mathrm{bpdc})_{2}\right] \cdot 3 \mathrm{H}_{2} \mathrm{O}(\mathrm{M}=\mathrm{Ni}, \mathrm{Cu})$ [37]. Here, the water molecules are not coordinated to either metal ion but the dimensions of the

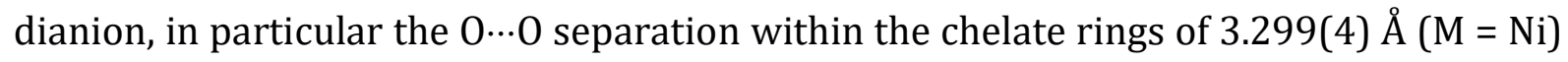
and 3.307(6) $\AA$ ( $\mathrm{M}=\mathrm{Cu}$ ) are virtually identical and very close to those of complex $\mathbf{1}$ (see above). Variations in the separation of the carboxylate groups are possible by changes in the degree of twisting about the aromatic ring link and the NCCN dihedral angles of 115 ${ }^{\circ}$ in the structures of the $\left[\mathrm{M}(\text { terpy })_{2}\right]\left[\mathrm{UO}_{2}(\mathrm{bpdc})_{2}\right] \cdot 3 \mathrm{H}_{2} \mathrm{O}$ complexes are again close to that of complex $1\left(118^{\circ}\right)$ but quite different to that $\left(105^{\circ}\right)$ of the complex $\left[\mathrm{UO}_{2}(\mathrm{bpdc})\right.$ (terpy)] $\cdot \mathrm{H}_{2} \mathrm{O}$ [37], where the $0 \cdots 0$ (chelate) separation is 3.009(4) $\AA$. Here, the $\mathrm{N}_{3} \mathrm{O}_{2}$ equatorial garland is significantly nonplanar, consistent with repulsive interaction between the two ligands being accommodated in at least two ways and certainly with changes in the 0 -chelate dimensions being associated with rotational barriers which must be close to minimal.

In complex 1, interactions of the dimethylammonium countercation with the anion are more complicated than in the earlier examples due the ability of the countercation to act (as is evident on examining the Hirshfeld surface $[45,46]$ ) as both 
an $\mathrm{NH}$ and $\mathrm{CH}$ donor in interacting with the $\mathrm{O}$ - and $\mathrm{N}$-atoms of the bound ligands. In part, this leads to the formation of $\mathrm{H}$-bonded polymer chains involving $\mathrm{NH} \cdots \mathrm{O} / \mathrm{N}$ interactions of the cation with carboxylate groups and the pyridine rings (Fig. 2a) [N3‥N1 2.880(5)

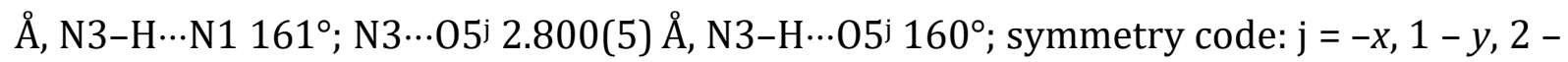

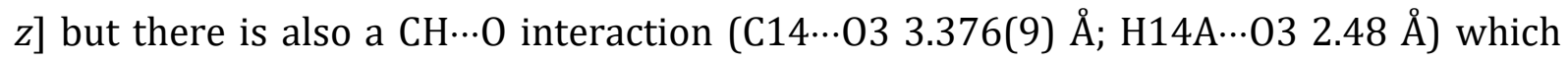
results in the cation spanning the two ligands on one uranyl centre and blocking potential additional coordination sites in the same way as free or coordinated water as in the examples cited above (Fig. 2b). In all known cases, therefore, it appears possible that the low coordination number of the U(VI) centres may be a consequence of the blockage of additional coordination sites by the close association of the anionic complex either with its countercation or with solvent.

Complex 2, $[\mathrm{pyH}]_{2}\left[\mathrm{UO}_{2}\right.$ (btfac) $\left.\left(\mathrm{NO}_{3}\right)_{2}\right]\left(\mathrm{NO}_{3}\right)$, is an analogue of structurally characterised species $[47,48]$ containing anions with acetylacetonate (acac ${ }^{-}$) in place of btfac $^{-}$and in which the uranium(VI) is also in a hexagonal-bipyramidal environment as seen in 2 (Fig. 3). The uranyl cation is chelated by the btfac- ligand and by two nitrate anions, with U-O bond lengths in the usual ranges [U-O(oxo) 1.764(4) and 1.768(4) $\AA$, U-O(diketonato) 2.361(4) and 2.359(4) $\AA$, U-O(nitrato) 2.512(4)-2.529(4)]. Significantly, bis(diketonato)uranyl ion species appear to be resistant to accepting a

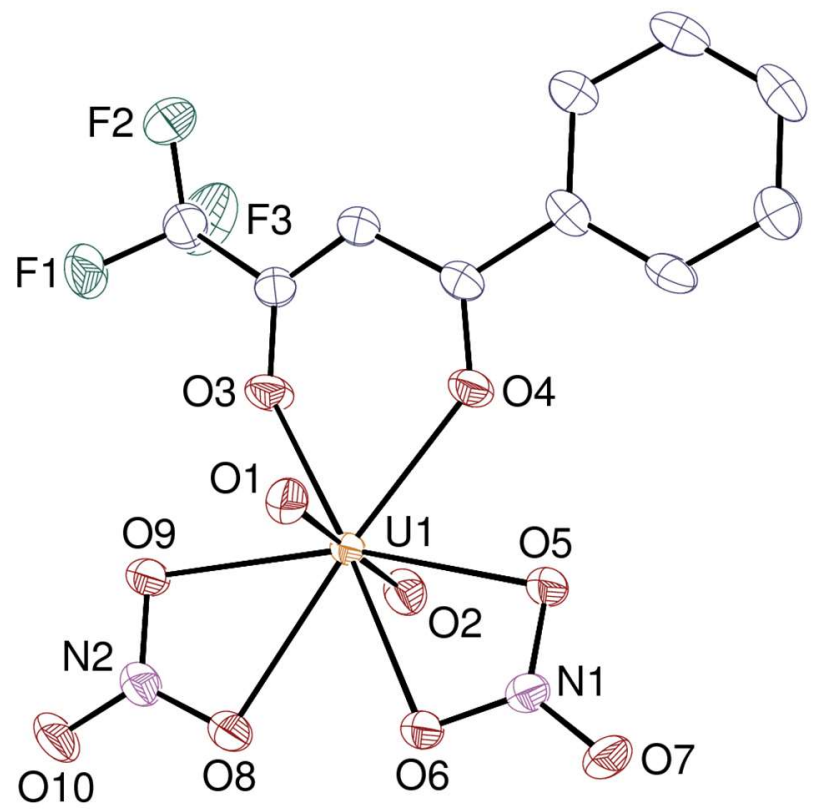

Fig. 3 View of the $\left[\mathrm{UO}_{2}(\mathrm{tfbzac})\left(\mathrm{NO}_{3}\right)_{2}\right]^{-}$anion in 2. Displacement ellipsoids are drawn at the $50 \%$ probability level. Hydrogen atoms are omitted and the rotational disorder of the $\mathrm{CF}_{3}$ group is not shown. 
bidentate ligand [48-50] but will accept one extra donor atom in forming a variety of pentagonal-bipyramidal species, two such having been structurally characterised with btfac $^{-}[51,52]$ and even the simple dimer of anhydrous $\mathrm{UO}_{2}$ (acac) 2 being one example [53], this behaviour being taken conventionally to mean that it is the small bite and thus the reduced repulsive interactions of nitrate that enable $\left[\mathrm{UO}_{2} \text { (diketonate) }\left(\mathrm{NO}_{3}\right)_{2}\right]^{-}$ anions to form. It has of course been argued that chelating nitrate could well be considered as occupying a single coordination site on a metal ion [54], meaning that in this sense the $\left[\mathrm{UO}_{2}(\mathrm{btfac})\left(\mathrm{NO}_{3}\right)_{2}\right]^{-}$anion could be regarded as containing again $\mathrm{U}(\mathrm{VI})$ in square pyramidal coordination. More significant may be the fact that known structurally characterised $\left[\mathrm{UO}_{2} \text { (diketonate) }\left(\mathrm{NO}_{3}\right)_{2}\right]^{-}$anions all involve protonated aza-aromatic countercations which are involved in multiple $\mathrm{CH} \cdots \mathrm{O}$ interactions with both nitrate ligands (Fig. 4), again raising the possibility that it is not just interactions within the equatorial coordination sphere that determine its occupancy. Additionally, the uncoordinated nitrate anion in $\mathbf{2}$ is hydrogen bonded to the two pyridinium cations,

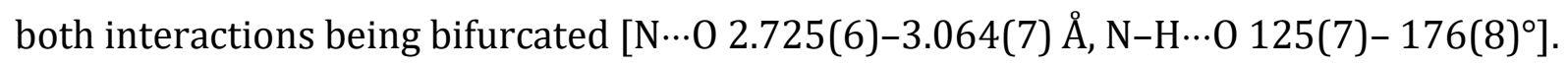
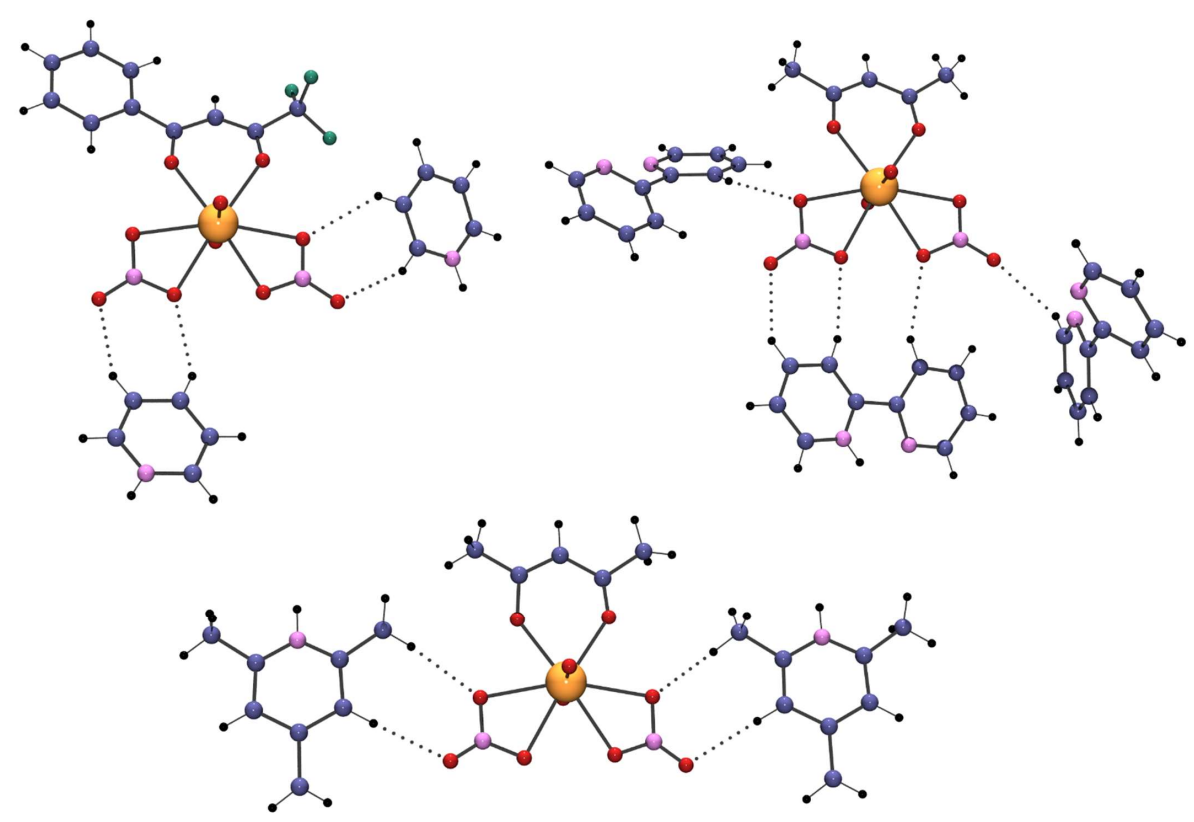

Fig. $4 \mathrm{CH} \cdots \mathrm{O}$ interactions (dotted lines) in $\left[\mathrm{UO}_{2} \text { (diketonate) }\left(\mathrm{NO}_{3}\right)_{2}\right]^{-}$anions. ( $\mathrm{NH} \cdots \mathrm{O}$ and $\mathrm{NH} \cdots \mathrm{N}$ interactions not shown).

The unique uranyl cation in the complex $\left[\mathrm{H}_{2} \mathrm{dabco}\right]\left[\mathrm{UO}_{2}(\mathrm{nta})\right]_{2} \cdot 3 \mathrm{H}_{2} \mathrm{O}(3)$ is $\mathrm{O}, \mathrm{N}, \mathrm{O}-$ chelated by one nta $^{3-}$ ligand and it is further bound to two carboxylate donors from two more ligands, the uranium environment being thus pentagonal-bipyramidal, as shown in Fig. 5 [U-O(oxo) 1.773(5) and 1.774(5) A, U-O(carboxylato) 2.313(5)-2.390(4) $\AA, \mathrm{U}-\mathrm{N}$ 


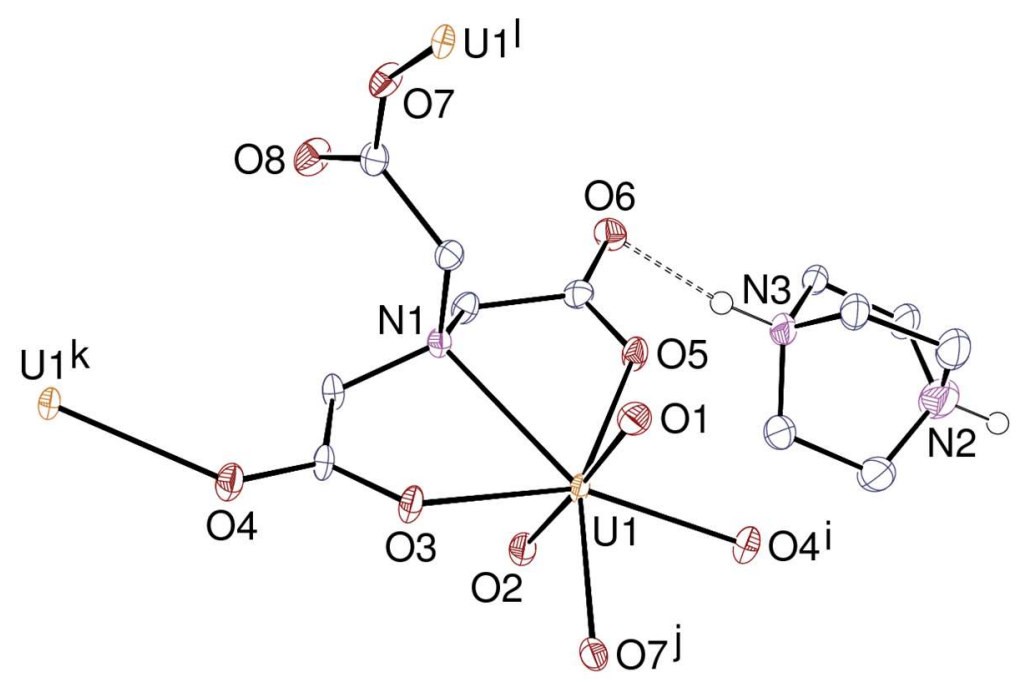

Fig. 5 View of the cation-anion association in $\left[\mathrm{H}_{2} \mathrm{dabco}\right]\left[\mathrm{UO}_{2}(\mathrm{nta})\right]_{2} \cdot 3 \mathrm{H}_{2} \mathrm{O}$ (3). Displacement ellipsoids are drawn at the $50 \%$ probability level. Carbon-bound hydrogen atoms are omitted and the hydrogen bond is shown as a dashed line. Only one position of the disordered $\mathrm{H}_{2} \mathrm{dabco}^{2+}$ cation is shown. Symmetry codes: $\mathrm{i}=3 / 2-x, y-1 / 2, z ; \mathrm{j}=3 / 2-x, 3 / 2-y, z+1 / 2 ; \mathrm{k}=3 / 2-x, y+1 / 2, z ; \mathrm{l}=3 / 2-x, 3 / 2-y, z-1 / 2$.

2.625(5) Å]. The nta ${ }^{3-}$ ligand is thus bound to three metal cations, with one carboxylate group bridging in the anti/anti $\mu_{2}-\kappa^{1} O: \kappa^{1} O^{\prime}$ mode and the other two monodentate. Both metal and ligand are thus 3-coordinated (3-c) nodes in the uninodal diperiodic coordination polymer formed, which is parallel to (100) and has the vertex symbol $\left\{6^{3}\right\}$ and the hcb topological type (Fig. 6). The disordered $\mathrm{H}_{2} \mathrm{dabco}^{2+}$ cations, located between

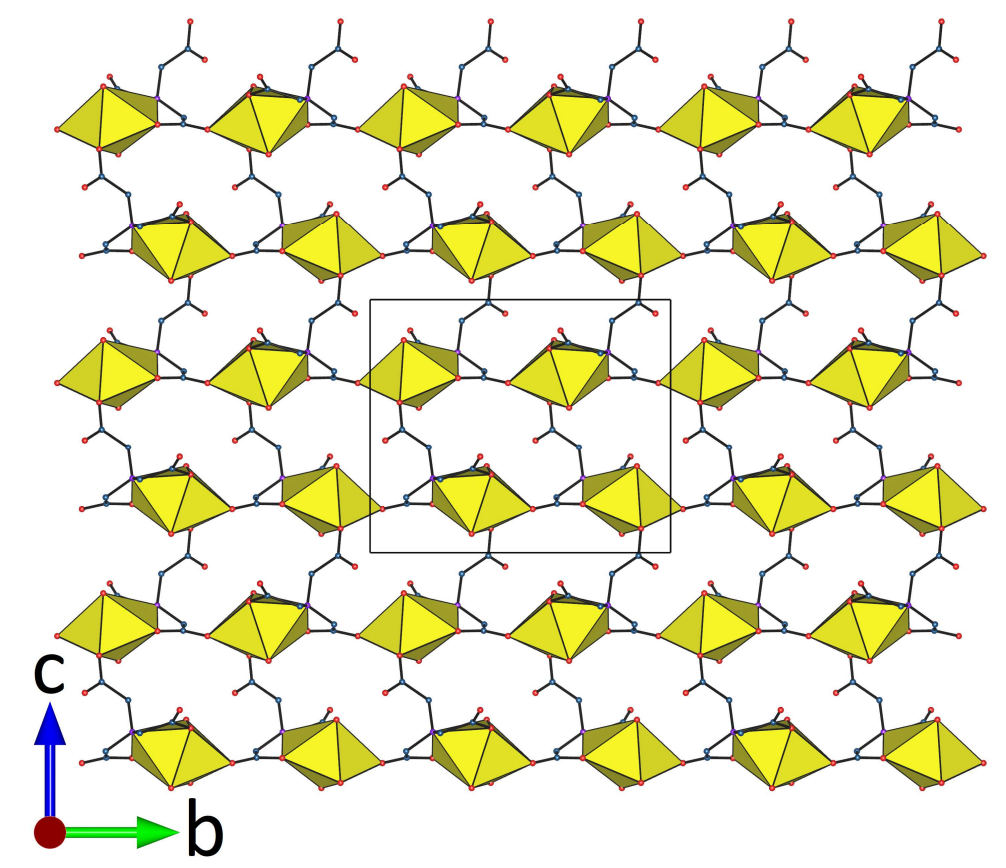

Fig. 6 View of the honeycomb-type network in 3. 


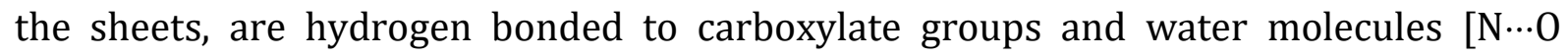

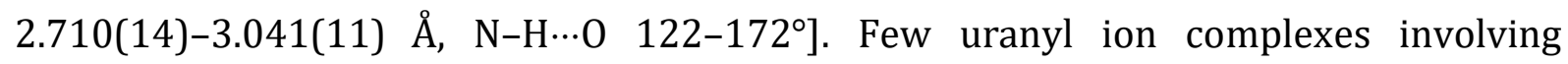
nitrilotriacetate are known, none involving U-N coordination; where the central nitrogen atom is protonated, the three carboxylate groups are monodentate and a monoperiodic ribbon-like coordination polymer is formed $[55,56]$ while, in the presence of additional Ni(II) cations, a triperiodic framework is obtained [57] in which the nta ${ }^{3-}$ is bound in a tridentate ONO manner to Ni(II) and interactions with the uranyl ions involve carboxylate groups only through monodentate and $\mu_{2}-\kappa^{1} O: \kappa^{1} O^{\prime}$ coordination. Interestingly, the difference between $\mathrm{Ni}-\mathrm{N}$ and $\mathrm{Ni}-\mathrm{O}$ bond lengths (mean values 2.08 and $2.03 \AA$, respectively) to the bound $n t^{3-}$ is only $0.05 \AA$. The principal features worthy of note in the present case are: (i) that it appears that the essentially planar nature of the equatorial uranyl coordination sphere prevents tripodal coordination of the nitrilotriacetate ligand to a single centre, thus leaving one carboxylate free for interaction with a separate uranyl ion, even though this still results in only a di- rather than a tri-periodic coordination polymer; (ii) that in the tridentate unit the $\mathrm{U}-\mathrm{N}$ bond length is considerably greater, by $\sim 0.27 \AA$, than that of the $U-0$, although it is similar to, if slightly shorter than, values known for 2,2'-bipyridine and 1,10-phenanthroline complexes, see e.g. [58].

Rather similar differences in U-N and U-O bond lengths to those in $\mathbf{3}$ are seen in complexes of the related ligand, iminodiacetate (ida ${ }^{2-}$ ] [59,60]. In a series of remarkable nanotube-forming, hexanuclear metallacycle species where the ligand takes an ONO tridentate form as the dianion but is also bidentate-bridging in a zwitterionic monoprotonated form as $\left(-\mathrm{O}_{2} \mathrm{CCH}_{2}\right)_{2} \mathrm{NH}_{2}{ }^{+}$, the mean $\mathrm{U}-\mathrm{N}$ and $\mathrm{U}-\mathrm{O}$ values are close to 2.58 and $2.36 \AA$, respectively, with no systematic differences between the U-O distances for the chelating and bridging groups [59]. The bridging role for the ligand, where it acts simply as an 0-donor, is possibly just another reflection of the oxophilicity of uranyl ion but may also indicate that a U-N separation $\sim 2.6 \AA$ is close to the limit of what may be considered a bonding distance. In the simpler complex $\left[\mathrm{H}_{2} \mathrm{Q}\right]\left[\left(\mathrm{UO}_{2}\right)_{2}(\mathrm{OH})_{2}(\mathrm{ida})_{2}\right](\mathrm{Q}=$ quinuclidine) [60], essentially identical values of $r_{\mathrm{U}-\mathrm{N}}$ and $r_{\mathrm{U}-\mathrm{O}}$ apply. That dicarboxylate chelation might enforce coordination of weaker donors held between the carboxylates is also implicit in what is seen in complexes of 2,2'-bipyridine-3,3';6,6'-tetracarboxylate (bptc ${ }^{4-}$ ) [43], where chelation of the bipyridine unit between two carboxylates is associated with significantly shorter U-N bond lengths than in simple bipyridine 
complexes [58] where the coordination number and coordination sphere composition are the same.

Somewhat surprisingly, given the supposed oxophilicity of U(VI), when the N of $\mathrm{ida}^{2-}$ is changed to $\mathrm{O}$ of oxydiacetate (oda ${ }^{2-}$ ), a uranyl complex, [ $\left.\mathrm{H}_{2} \mathrm{tmen}\right]\left[\mathrm{UO}_{2}\right.$ (oda) 2$]$ (tmen = tetramethylethylenediamine) can be isolated [60] in which one ligand is bound in a tridentate manner with U-O(carboxylate) 2.352(7) $\AA$ and U-O(ether) 2.564(10) $\AA$ but the other is bound in a bidentate manner through the carboxylate donors only, with U-O(carboxylate) 2.376(8) ̊̊ and (nonbonding) U...O(ether) 3.111(12) Å. The Hirshfeld surface of the complex provides no evidence for interactions beyond dispersion with the uncoordinated ether- 0 , so it does not appear that there is an external cause of its detachment, implying that the energy of the U-O(ether) bond must be rather small, with its involvement leading to a barely significant decrease in the U-O(carboxylate) bond length associated with a change in the bound ligand conformation, implying that the U$\mathrm{O}$ (ether) bond energy may be comparable to the conformational barrier. When the $\mathrm{O}$ of oxydiacetate is changed to the poorer Lewis base $S$ in thiodiglycolate ( $\operatorname{tgg}^{2-}$ [61], the ligand behaves solely as a bis $\left(\kappa^{1} O, \kappa^{1} O\right)$ chelate bridging ligand, with no U..S interaction, very much showing the same uranyl ion coordination chemistry as its analogue glutarate where $\mathrm{CH}_{2}$ replaces $\mathrm{S}$ [62].

Similar basic features to those of $\mathbf{3}$ can be discerned in the structure of complex $\mathbf{4}$, $\left[\mathrm{Ni}(\right.$ cyclam $) \mathrm{UO}_{2}$ (edta)] $2 \mathrm{H}_{2} \mathrm{O}$, where the edta ${ }^{4-}$ ligand acts as a bis(tridentate) bridging unit. The unique uranium atom, located on an inversion centre, is $\mathrm{O}, \mathrm{N}, \mathrm{O}$-chelated by two ligands and is thus in a hexagonal-bipyramidal environment [U-O(oxo) 1.785(3) $\AA$, UO(carboxylato) 2.364(3) and 2.397(3) Å, U-N 2.788(3) Å] (Fig. 7). The U-N bond length here is significantly longer than that in complex $\mathbf{3}$, which is probably due to the pressure of the greater number of equatorial donors in $\mathbf{4}$, and indeed somewhat longer also than in the mixed-ligand, $\left(\mathrm{H}^{+}\right) \mathrm{edta}^{4-}$ containing complexes $\left[\mathrm{K}_{4}\left[\left(\mathrm{UO}_{2}\right)_{4}\left(\mathrm{O}_{2}\right)_{2}(\mathrm{Hedta})_{2}\left(\mathrm{IO}_{3}\right)_{2}\right] \cdot 16 \mathrm{H}_{2} \mathrm{O}\right.$ and $\mathrm{LiK}_{3}\left[\left(\mathrm{UO}_{2}\right)_{4}\left(\mathrm{O}_{2}\right)_{2}(\mathrm{edta})_{2}\left(\mathrm{H}_{2} \mathrm{O}\right)_{2}\right] \cdot 18 \mathrm{H}_{2} \mathrm{O}$ [63] which include small-bite peroxo bridges and in which the U-N bond lengths range between 2.665(6) and 2.758(6) $\AA$. The Ni(II) cation in 4 is bound to the four nitrogen atoms of the cyclam macrocycle and it makes two longer axial contacts with two carboxylate oxygen atoms, being thus in a slightly elongated octahedral environment 


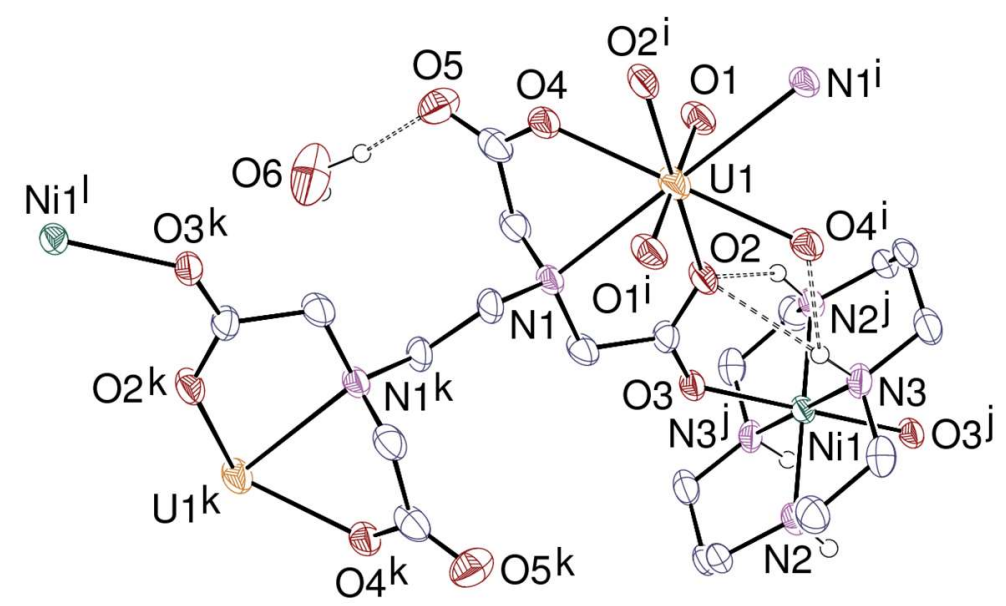

Fig. 7 View of $\left[\mathrm{Ni}(\right.$ cyclam $) \mathrm{UO}_{2}($ edta $\left.)\right] \cdot 2 \mathrm{H}_{2} \mathrm{O}$ (4). Displacement ellipsoids are drawn at the $50 \%$ probability level. Carbon-bound hydrogen atoms are omitted and hydrogen bonds are shown as dashed lines. Symmetry codes: $\mathrm{i}=1-x, 1-y, 1-z ; \mathrm{j}=1-x, 1-y, 2-z ; \mathrm{k}=2-x, 1-y, 1-z ; \mathrm{l}=x+1, y, z-1$.

[Ni-N 2.060(4) and 2.071(4) $\AA, \mathrm{Ni}-\mathrm{O} 2.120(3) \AA]$. The cyclam NH groups are hydrogen

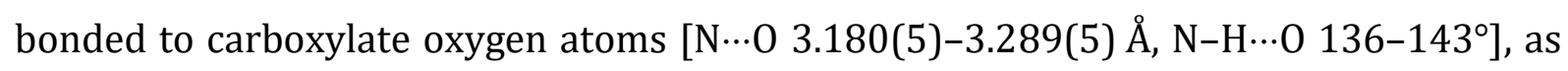
usual in such complexes [20], the longer of these interactions causing the $[\mathrm{Ni}(\text { cyclam })]^{2+}$ unit to bridge and thus block the gap between ligand units on uranyl ion, just as in complex 3 and its analogues. Two carboxylate groups of the ligand bridge uranium and nickel ions in the syn/anti $\mu_{2}-\kappa^{1} O: \kappa^{1} O^{\prime}$ mode, and the other two are monodentate. The ligands link uranyl centres into chains running down [100], these being assembled by the $\mathrm{Ni}(\mathrm{II})$ cations into a diperiodic polymeric assembly parallel to (010). Both metal cations are simple links and edta ${ }^{4-}$ is a 4-c node, the uninodal network having the $\left\{4^{4} .6^{2}\right\}$ vertex symbol and the sql topological type (Fig. 8). The water molecules bridge the layers through hydrogen bonding to carboxylato and oxo groups [0… 2.745(5) and 2.953(5) $\AA, 0-\mathrm{H} \cdots 0162$ and 165º. The considerable variations in U-N bond lengths seen in these complexes are consistent with a weak $\mathrm{U}-\mathrm{N}$ interaction compared to U-O being more subject to significant influence by otherwise subtle differences in structural factors. 

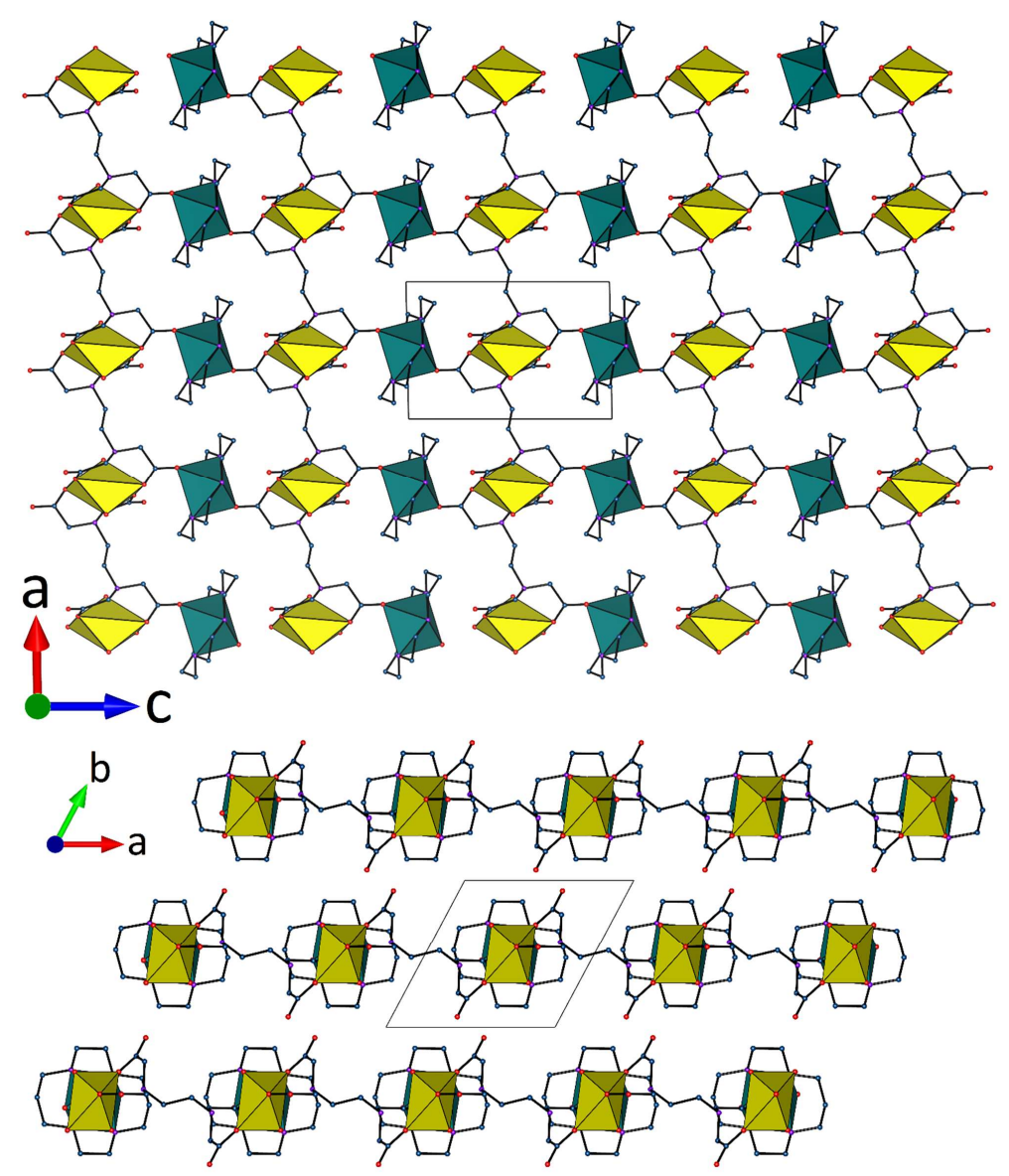

Fig. 8 Views of the diperiodic network (top) and of the packing of layers (bottom) in 4. Hydrogen atoms and solvent molecules are omitted.

\section{Conclusions}

The four structures discussed herein can be placed in a context of numerous similar ones which show the same influences on the overall structure arising from interactions outside the primary coordination sphere of the uranyl ion. It is of course accepted on the basis of theoretical work that both repulsive and attractive interactions within this coordination sphere and its immediately adjacent atoms are important and can have a major effect on individual bond energies [64] but the fact that estimates of $\mathrm{UO}_{2}$-(donor atom)equatorial bond energies $[64,65]$ are not necessarily much greater than the energy of interactions such as H-bonding justifies the hypothesis that what is observed in the solid state regarding the coordination number of uranyl ion may indeed be a feature of that state only. In addition, structures of the uranyl ion complexes of aliphatic ligands where two carboxylate groups are linked by $\mathrm{H}_{2} \mathrm{CXCH}_{2}(X=N R, O, S)$ units are interesting in that they show that detachment of the central atom from U(VI) can be associated with a relatively minor conformational change, indicating that the bond energy must be small, 
although it is also important to note that even with chelating nitrate, where $\mathrm{U} \cdots \mathrm{N} \sim 2.9 \AA$, theory [64] indicates that the $\mathrm{U} \cdots \mathrm{N}$ interaction makes a significant contribution to the ligand binding. Here again it is plausible that the strong U-O interaction enforces this U$\mathrm{N}$ contact just as it may do in complexes of iminodiacetate, nitrilotriacetate and 2,2'bipyridine-3,3';6,6'-tetracarboxylate (bptc-5).

\section{References}

1. Kepp, K. P.: A quantitative scale of oxophilicity and thiophilicity. Inorg. Chem. 55, 9461-9470 (2016).

2. Cotton, S. A.: Lanthanide and Actinide Chemistry, Wiley \& Sons, Ch. 11, ISBN: 978-0-470-01005-1 (2006).

3. Rudel, S. S., Deubner, H. L., Müller, M., Karttunen, A. J., Kraus, F.: Complexes Featuring a Linear $[\mathrm{N} \equiv \mathrm{U} \equiv \mathrm{N}]$ Core Isoelectronic to the Uranyl Cation. Nature Chem. 12, 962-967 (2020).

4. Fortier, S., Hayton, T. W.: Oxo Ligand Functionalisation in the Uranyl Ion $\left(\mathrm{UO}_{2}{ }^{2+}\right)$. Coord. Chem. Rev. 254, 197-214 (2010).

5. Leciejiewicz, J., Alcock, N. W., Kemp, T.J.: Carboxylato Complexes of the Uranyl Ion: Effects of Ligand Size and Coordination Geometry upon Molecular and Crystal Structure. Struct. Bonding. 82, 43-84 (1995).

6. Loiseau, T., Mihalcea, I., Henry, N., Volkringer, C.: The Crystal Chemistry of Uranium Carboxylates. Coord. Chem. Rev. 266-267, 69-109 (2014).

7. Harrowfield, J., Thuéry, P.: Uranyl Ion Complexes of Polycarboxylates: Steps towards Isolated Photoactive Cavities. Chemistry 2, 63-79 (2020).

8. Thuéry, P., Nierlich, M., Masci, B., Asfari, Z., Vicens, J.: An unprecedented trigonal coordination geometry for the uranyl ion in its complex with $p$-tertbutylhexahomotrioxacalix[3]arene. J. Chem. Soc. Dalton Trans 3151-3152 (1999).

9. Masci, B., Nierlich, M., Thuéry, P.: Supramolecular Assemblies from Uranyl Ion Complexes of Hexahomotrioxacalix[3]arenes and Protonated [2.2.2] Cryptand. New J. Chem. 26, 766-774 (2002).

10. Burns, C. J., Clark, D. L., Donohoe, R. J., Duval, P. B., Scott, B. L., Tait, C. D.: A Trigonal Bipyramidal Uranyl Amido Complex: Synthesis and Structural 
Characterization of $\left[\mathrm{Na}(\mathrm{THF})_{2}\right]\left[\mathrm{UO}_{2}\left(\mathrm{~N}\left(\mathrm{SiMe}_{3}\right)_{2}\right)_{3}\right]$. Inorg. Chem. 39, 5464-5468 (2000).

11. Zachariasen, W. H., Plettinger, H. A.: Crystal Chemical Studies of the 5f-Series of Elements. XXV. The Crystal Structure of Sodium Uranyl Acetate. Acta Cryst. 12, 526-530 (1959).

12. Deshayes, L., Keller, N., Lance, Nierlich, M., Vigner, J.-D.: Pentaaquadioxouranium(VI) Triflate-18-crown-6, Acta Cryst. C50, 1541-1544 (1994).

13. Fischer, A.: Competitive Coordination of the Uranyl Ion by Perchlorate and Water - The Crystal Structures of $\mathrm{UO}_{2}\left(\mathrm{ClO}_{4}\right)_{2} \cdot 3 \mathrm{H}_{2} \mathrm{O}$ and $\mathrm{UO}_{2}\left(\mathrm{ClO}_{4}\right)_{2} \cdot 5 \mathrm{H}_{2} \mathrm{O}$ and a Redetermination of $\mathrm{UO}_{2}\left(\mathrm{ClO}_{4}\right)_{2} \cdot 7 \mathrm{H}_{2} \mathrm{O}$. Z. Anorg. Allg. Chem. 629, 1012-1016 (2003).

14. Deshayes, L., Keller, N., Lance, M., Navaza, A., Nierlich, M., Vigner, J.: EXAFS Analysis of Aqueous and Acetonitrile Solutions of $\mathrm{UO}_{2}$-Triflate with Crown Ethers and Aza-crowns. Crystal Structures of the Inclusion Complexes UO2(18-crown6) $\left(\mathrm{CF}_{3} \mathrm{SO}_{3}\right)_{2}$ and $\mathrm{UO}_{2}$ (Dicyclohexyl-18-crown-6) $\left(\mathrm{CF}_{3} \mathrm{SO}_{3}\right)_{2}$. Polyhedron 13, 4725-4733 (1994) and references therein.

15. Wahlgren, U., Moll, H., Grenthe, I., Schimmelpfennig, B., Maron, L., Valet, V., Gropen, O.: Structure of Uranium(VI) in Strong Alkaline Solutions. A Combined Theoretical and Experimental Investigation. J. Phys. Chem. A 103, 8257-8264 (1999).

16. Buhl, M., Kabrede, H.: Mechanism of Water Exchange in Aqueous Uranyl(VI) Ion. A Density Functional Molecular Dynamics Study. Inorg. Chem. 45, 3834-3836 (2006).

17. Parker, T. G., Cross, J. N., Polinski, M. J., Lin, J., Albrecht-Schmitt, T. E.: Ionothermal and Hydrothermal Flux Syntheses of Five New Uranyl Phosphonates. Cryst. Growth Des. 14, 228-235 (2014).

18. Berthet, J.-C., Nierlich, M., Ephritikhine, M.: A Novel Coordination Geometry for

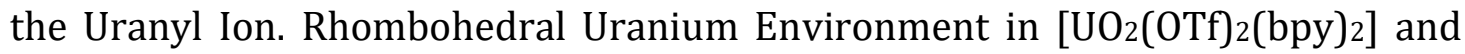
$\left.\left[\mathrm{UO}_{2} \text { (phen) }\right]_{3}\right][\mathrm{OTf}]_{2}$. Chem. Commun. 1660-1661 (2003).

19. Sarsfield, M. J., Helliwell, M., Raftery, J.: Distorted Equatorial Coordination Environments and Weakening of $\mathrm{U}=0$ Bonds in Uranyl Complexes Containing NCN and NPN Ligands. Inorg. Chem. 43, 3170-3179 (2004). 
20. Thuéry, P., Harrowfield, J.: $[\mathrm{Ni}(\text { cyclam })]^{2+}$ and $\left[\mathrm{Ni}\left(R, S-\mathrm{Me}_{6} \text { cyclam }\right)\right]^{2+}$ as Linkers or Counterions In Uranyl-Organic Species with cis- and trans-1,2Cyclohexanedicarboxylate Ligands. Cryst. Growth Des. 18, 5512-5520 (2018).

21. Hooft, R. W. W.: COLLECT, Nonius BV: Delft, The Netherlands (1998).

22. APEX3 Crystallography Software Suite, Ver. 2019.1-0; Bruker AXS: Madison, WI, USA (2019).

23. Otwinowski, Z., Minor, W.: Processing of X-Ray Diffraction Data Collected in Oscillation Mode. Methods Enzymol. 276, 307-326 (1997).

24. SAINT, Ver. 8.40A; Bruker Nano: Madison, WI, USA (2019).

25. SADABS, Bruker/Siemens Area Detector Absorption and Other Corrections, Ver. 2016/2; Bruker AXS: Madison, WI, USA (2016).

26. Sheldrick, G. M.: SHELXT - Integrated Space-Group and Crystal-Structure Determination. Acta Cryst. A71, 3-8 (2015).

27. Sheldrick, G. M.: Crystal Structure Refinement with SHELXL. Acta Cryst. C71, 3-8 (2015).

28. Hübschle, C. B., Sheldrick, G. M., Dittrich, B.: ShelXle: a Qt Graphical User Interface for SHELXL. J. Appl. Crystallogr. 44, 1281-1284 (2011).

29. Farrugia, L. J.: WinGX and ORTEP for Windows: an Update. J. Appl. Crystallogr. 45, 849-854 (2012).

30. Momma, K., Izumi, F.: VESTA 3 for Three-Dimensional Visualization of Crystal, Volumetric and Morphology Data. J. Appl. Crystallogr. 44, 1272-1276 (2011).

31. Blatov, V. A., Shevchenko, A. P., Proserpio, D. M.: Applied Topological Analysis of Crystal Structures with the Program Package ToposPro. Cryst. Growth Des. 14, 35763586 (2014).

32. Groom, C. R., Bruno, I. J., Lightfoot, M. P., Ward, S. C.: The Cambridge Structural Database. Acta Cryst. B72, 171-179 (2016).

33. Ravikumar, K., Swamy, G. Y. S. K., Lakshmi, N. V., Chandramohan, K.: Molecular interactions in substituted 2,2'-bipyridines: crystal structures of 2,2'-bipyridine3,3'-dicarboxylic acid monohydrate and (2,2'-bipyridine-3,3'-dicarboxylic acid)dichlorocopper(II) dihydrate. J. Chem. Crystallogr. 27, 119-124 (1997).

34. Zhao, B. Z., Hao, X. R., Han, Z. G., Fu, Q., Chen, Y. G.: A Novel Cu(II) Coordination Polymer with 2,2'-bipyridine-3,3'-dicarboxylic acid. Acta Cryst. C61, m48-m50 (2003). 
35. Swamy, G. Y. S. K., Chandramohan, K., Lakshmi, N. V., Ravikumar, K.: Crystal Structure of Catena-poly[tetraaqua(2,2'-bipyridine-3,3'-dicarboxylato)Mn(II)]. Z. Krist. - Cryst. Materials 213, 191-194 (1998).

36. Burnet, S., Hall, A.K., Harrowfield, J. M., Koutsantonis, G. A., Sanford, V., Sauter, D., Skelton, B. W., White, A. H.: Alkali Metal Complexes of Aromatic Polycarboxylates - A Balance of $\pi$-stacking and Coordinate Bonding Interactions ? Supramol. Chem. 15, 291-312 (2003).

37. Gomez, G. E., Ridenour, J. A., Byrne, N. M., Shevchenko, A. P., Cahill, C. L.: Novel Heterometallic Uranyl-Transition Metal Materials: Structure, Topology, and Solid State Photoluminescence Properties. Inorg. Chem. 58, 7243-7254 (2019).

38. Hancock, R. D., Martell, A. E.: Ligand Design for Selective Complexation of Metal Ions in Aqueous Solution. Chem. Rev. 89, 1875-1914 (1989).

39. Cousson, A., Proust, J., Pagès, M., Robert, F.,. Rizkalla, E.: structure of Dibenzoatodioxouranium(VI). Acta Cryst. C46, 2316-2318 (1990).

40. Milhacea, I., Henry, N., Bousquet, T., Volkringer, C., Loiseau, T.: Sixfold Coordinated Uranyl Cations in Extended Coordination Polymers. Cryst. Growth Des. 12, 4641-4648 (2012).

41. Thuéry, P., Harrowfield, J.: Structural Consequences of cis/trans Isomerism of 1,4Cyclohexanedicarboxylate in its Complexes with Uranyl Ion: from Molecular Species to 2D and 3D Entangled Nets. Inorg. Chem. 56, 13464-13481 (2017).

42. Thuéry, P., Harrowfield, J.: Coordination Polymers and Cage-Containing Frameworks in Uranyl Ion Complexes with rac- and $(1 R, 2 R)$-trans-1,2Cyclohexanedicarboxylates: Consequences of Chirality. Inorg. Chem. 56, 1455-1469 (2017).

43. Zhao, R., Li, F.-Z., Lu, J.-P., Mei, L., Hu, K.-Q., Chai, Z.-F., Shi, W.-Q.: A New Preorganised Metalloligand Linker for the Construction of Luminescent Coordination Polymers. Cryst. Growth Des. 20, 6966-6972 (2020).

44. Thuéry, P., Harrowfield, J.: Zero-, mono- and diperiodic uranyl ion complexes with the diphenate dianion: influences of transition metal ion coordination and differential UVI chelation. Dalton Trans 49, 817-828 (2020).

45. Wolff, S. K., Grimwood, D. J., McKinnon, J. J., Turner, M. J., Jayatilaka, D., Spackman, M. A.: CrystalExplorer 3.1, University of Western Australia (2012).

46. McKenzie, C. F., Spackman, P. R., Jayatilaka, D., Spackman, M. A.: IUCrJ 4, 575-587 
(2017).

47. Alcock, N. W., Flanders, D. J.: Actinide Structural Studies 14: Two Uranyl Complexes containing 2,4-pentanedione. Acta Cryst. C43, 1480-1483 (1987).

48. Kawasaki, T., Nishimura, T.: Uranyl(VI) Acetylacetonate Coordination Compounds with Various N-Heterocyclic Ligands. Bull. Chem. Soc. Jpn 83, 1528-1530 (2010).

49. Comyns, A. E., Gatehouse, B. M., Wait, E.: The Chemistry of Uranyl Acetylacetonate Complex. J. Chem. Soc. 4655-4665 (1958).

50. Vigato, P. A., Peruzzo, V., Tamburini, S.: The evolution of $\beta$-diketone or $\beta$ diketophenol ligands and related complexes. Coord. Chem. Rev. 253, 1099-1201 (2009).

51. Charpin, P., Lance, M., Nierlich, M., Vigner, D.: Etude Structurale de l'(Hexaméthylphosphoramide)dioxobis(trifluoro-1 phényl-4 butanedionato2,4)uranium(VI). Acta Cryst. C42, 987-989 (1986).

52. Zucchi, G., Thuéry, P.: CSD Communication, refcode GOKVUZ (2010).

53. Sidorenko, G. V., Grigor'ev, M. S., Guzhii, V. V., Suglobov, D. N., Tananaev, I. G.: Crystal and Molecular Structure of Uranyl Acetylacetonate Dimer, $\left[\mathrm{UO}_{2}\left(\mathrm{C}_{5} \mathrm{H}_{7} \mathrm{O}_{2}\right)_{2}\right] 2$. Radiokhimiya 51, 303-307 (2009) (Radiochemistry 51, 345349 (2009)).

54. Bergman, J. G., Cotton, F. A.: J. Am. Chem. Soc. 86, 2941-2942 (1964).

55. Grigoriev, M. S., Den Auwer, C., Meyer, D., Moisy, P.: Poly[[[diaquadioxouranium(VI)]- $\mu 3-$ nitrilotriacetato- $\left.\kappa^{3} O: O^{\prime}: O^{\prime}\right]$ trihydrate]. Acta Cryst. C 62, m163-m165 (2006).

56. Thuéry, P.: Uranyl ion complexation by the tripodal ligand nitrilotriacetate. Inorg. Chem. Commun. 10, 423-426 (2007).

57. Thuéry, P., Harrowfield, J.: Uranyl-organic frameworks with polycarboxylates: unusual effects of a coordinating solvent. Cryst. Growth Des. 14, 1314-1323 (2014).

58. Thuéry, P., Harrowfield, J.: Anchoring Flexible Uranyl Dicarboxylate Chains through Stacking Interactions of Ancillary Ligands on Chiral U(VI) Centres. CrystEngComm 18, 3905-3918 (2016).

59. Unruh, D. K., Gojdas, K., Libo, A., Forbes, T. Z.: Development of Metal-Organic Nanotubes Exhibiting Low-Temperature, Reversible Exchange of Confined "Ice Channels". J. Am. Chem. Soc. 135, 7398-7401 (2013). 
60. Jiang, J., Sarsfield, M. J., Renshaw, J. C., Livens, F. R., Collison, D., Charnock, J. M., Helliwell, M., Eccles, H.: Synthesis and Characterization of Uranyl Compounds with Iminodiacetate and Oxydiacetate Displaying Variable Denticity. Inorg. Chem. 41, 2799-2806 (2002).

61. Unruh, D. K., Libo, A., Streicher, L., Forbes, T. Z.: Synthesis and Characterisation of 1-D Uranyl Thiodiglycolate Coordination Polymers. Polyhedron 73, 110-117 (2014).

62. Borkowski, L. A., Cahill, C. L.: A Novel Uranium-containing Coordination Polymer: poly[Dioxouranium(VI)- $\mu_{4}-n$-pentane-1,5-dicarboxylato]. Acta Cryst. E61, m816m817 (2005).

63. Qiu, J., Ling, J., Sieradzki, C., Nguyen, K., Wylie, E. M., Szymanowski, J. E. S., Burns, P. C.: Expanding the Crystal Chemistry of Uranyl Peroxides: Four Hybrid UranylPeroxide Structures Containing EDTA. Inorg. Chem. 53, 12084-12091 (2014).

64. Ionov, S. V., Crabbe, C., Ionova, G. V.: Influence of Ligand Substitution on UraniumLigand Bond Energies in the Equatorial Plane of Uranyl Compounds. Russ. J. Coord. Chem. 28, 267-276 (2002).

65. Farkas, I., Banyai, I., Szabo, Z., Wahlgren, U., Grenthe, I.: Rates and Mechanisms of Water Exchange of $\mathrm{UO}_{2}{ }^{2+}(\mathrm{aq})$ and $\mathrm{UO}_{2}$ (oxalate) $\mathrm{F}\left(\mathrm{H}_{2} \mathrm{O}\right)_{2}{ }^{-}$: A Variable-Temperature ${ }^{170}$ and ${ }^{19}$ F NMR Study. Inorg. Chem. 39, 799-805 (2000). 